\title{
Cytological and Molecular studies in some interspecific hybrids resulted from crossing between tetraploid and hexaploid wheat
}

\author{
Demais $^{1}$, Seham M.; Bekhit ${ }^{1}$, M. M. M.;Abd El-Sabour ${ }^{1}$, M. S.; Salem ${ }^{1}$, T. M. S. and Gad ${ }^{2}$, K. I. \\ 1 Genetics and Genetic Engineering Dept., Faculty of Agriculture, Benha University, Egypt. \\ 2 Wheat Research Department, Agricultural Research Institute, Giza, Egypt \\ Corresponding author: makhlouf.bakhit@fagr.bu.edu.eg
}

\begin{abstract}
Wheat relatives are rich sources of beneficial genes that are capable to change the situation of the wheat strains. The present study attempted to cross three tetraploid wheat strains as male parents with five strains of hexaploid bread wheat to understand the behavior of hybrids in relation to cytology, Scanning Electron Microscopy for wheat grains and SDS-PAGE (Friabilin). Scanning electron microscopy of dry grains revealed morphological details of grain surface structure. The grains of strain 20 cultivar showed narrower size and hairless area than the grains of strain 9 or 17 or 6 . The hairy end of the strain 17 grains is broader than the same end (hairy) of the strain 21. The hairy end of the strain 24 is completely disappeared from grains. All the produced six crosses were containing hairy ends as an indicator for the inheritance of this character. Probably complete dominance of the gene controlling the brush area in the wheat grain. Various degrees of chromosome anomalies were seen with all the hybrids between $T$. durum and $T$. aestivum. D genome from $T$. aestivum could enhance more lagging chromosomes rather than genomes A and B of cultivated species. The main observed abnormalities in the produced crosses are the laggard formation. Fraibilin clearly associated with genetic proximity of the species, which characterized themselves by maintaining the genome homeology.
\end{abstract}

Key words: wide hybridization, Triticum, SDS-PAGE, Fraibilin, Laggards, meiotic anomalies, tetraploid wheat, bread wheat.

\section{Introduction}

Wheat is the main grain crop in cultivation and production in Egypt. The genetic variability within cultivated wheat is rapidly declined, mainly due to the replacement of the highly variable landraces with pure line varieties (Bhagyalakshmi et al., 2008.)

Wheat breeders aim to use progenitors of wheat (Triticum) and distant related species (durum) as supplementary sources to utilize from the beneficial genes (Tomar, et al., 2004). Different species belonging to the genus Triticum are different in their adaptation to a wide range of environments. They had a rich pool of genetic variability as genetic resistance to rusts, drought tolerance, Friabilin and high protein content in addition to yield characteristics. Moreover, diploid, tetraploid, and hexaploid wheat are related in one or more genomes with the cultivated wheat. These genomes play the main role in wheat improvement through gene introgression. The main goal from this study is the production of successful highly fertile interspecific hybrids. Interspecific crossing attempts were done between cultivated and wild wheat species of different ploidy levels have been reported (Bhagyalakshmi et al., 2008). To understand the behavior of chromosomes during the different stages of meiosis in the relative wheat species, crossing between these species is used to produce interspecific hybrids. It is necessary to utilize from the exotic gene pools for wheat improvement. Actually, the interspecific hybridization is still the major tool to the breeders especially wheat breeders. Scanning electron microscopy of dry grains revealed morphological details of grain surface structure (Haneen and Brismar (1987); Bekhit (2007); Kalkan and Palamanit (2017); Loutfy (1992); Zakowsky and Donald (2004); Moss (1985) and Salama, Hanan (2003)). The inheritance of kernel hardness is controlled by one or two major genes. A single gene located on the short arm of chromosome 5D has been shown to be the major determinant of endosperm texture variation in wheat and is estimated as accounting for $65 \%$ of the variation in endosperm texture between wheat cultivars (Law and Payne 1983). In the present study, three tetraploid wheat strains $(2 n=28)$ were crossed with five cultivated bread wheat varieties $(2 n=42)$. The study focused on the crossability of the hybrids, Scanning Electron Microscopy for wheat grains, cytogenetic behavior of the hybrids (chromosomal instability) as well as friabilin.

\section{Materials and Methods}

Interspecific hybridization

The crossing and field evaluation of the parents and interspecific hybrids were done at the Seds Station of Agricultural Research Centre, Giza, Egypt during the seasons of 2015/2016 and 2016/2017. The parent materials used were three new strains of tetraploid wheat ( $T$. durum as male parents and three cultivated varieties with two new strains of hexaploid wheat $(T$. aestivum) as female parents. Direct crossings were done between three tetraploids and five hexaploid (varieties and strains, Table 1). 
Table 1. The pedigree and origin of the tetraploid and hexaploid wheat strains used in production of six crosses.

\begin{tabular}{|c|c|c|c|}
\hline Ser & Pedigree & \multicolumn{2}{|c|}{ Crosses } \\
\hline 3 & $\begin{array}{l}\text { Sids } 8 \\
\text { /10/MÂALI/6/MUSK_1//ACO89/FNFOOT_2/4/MUSK_4/3/PLATA_3//CREX/ } \\
\text { ALLA/ } \\
\text { 5/OLUS*2/ILBOR//PATKA_7/YAZI_1/10/ALTAR 84//FD8419-126-1- } \\
\text { 2/RAZZAK/3/KRF-DW/BALADIA HAMRA/9/ALTAR } \\
\text { 84/860137//YAZI_1/4/LIS_8/FILLO_6/3/FUUT//HORA/JOR/8/GEDIZ/FGO// } \\
\text { GTA/3/SRN_1/4/TOTUS/5/ENTE/M }\end{array}$ & 2128 & $6 \times 20$ \\
\hline 7 & $\begin{array}{l}\text { Sids } 12 \\
\text { /10/MÂALI/6/MUSK_1//ACO89/FNFOOT_2/4/MUSK_4/3/PLATA_3//CREX/ } \\
\text { ALLA/5/OLUS*2/ILBOR// } \\
\text { PATKA_7/YAZI_1/10/ALTAR 84//FD8419-126-1-2/RAZZAK/3/KRF- } \\
\text { DW/BALADIA HAMRA/9/ALTAR } \\
\text { 84/860137//YAZI_1/4/LIS_8/FILLO_6/3/FUUT//HORA/JOR/8/GEDIZ/FGO// } \\
\text { GTA/3/SRN_1/4/TOTUS/5/ENTE/M }\end{array}$ & 2132 & $8 \times 20$ \\
\hline 10 & $\begin{array}{l}\text { Sids 13 } \\
\text { /10/MÂALI/6/MUSK_1//ACO89/FNFOOT_2/4/MUSK_4/3/PLATA_3//CREX/ } \\
\text { ALLA/5/OLUS*2/IL } \\
\text { BOR//PATKA_7/YAZI_1/10/ALTAR 84//FD8419-126-1-2/ } \\
\text { RAZZAK/3/KRF-DW/BALADIA HAMRA/9/ALTAR } \\
\text { 84/860137//YAZI_1/4/LIS_8/FILLO_6/3/FUUT// } \\
\text { HORA/JOR/8/GEDIZ/FGO//GTA/3/SRN_1/4/TOTUS/5/ENTE/M }\end{array}$ & 2135 & $9 \times 20$ \\
\hline 15 & $\begin{array}{l}\text { Maya's'/Mon's'//CMH74A592/3/*2Sakha8/4/Sohag3 /6/BELLAROI/5/1A.1D } \\
\text { 5+1-06/3*MOJO// } \\
\text { RCOL/4/ARMENT//SRN_3/NIGRIS_4/3/CANELO_9.1 }\end{array}$ & 2140 & $17 \times 21$ \\
\hline 17 & $\begin{array}{l}\text { Maya's'/Mon's'//CMH74A592/3/*2Sakha8/4/Sohag3 } \\
\text { /10/MÂALI/6/MUSK_1//ACO89/FNFOOT_2/4/MUSK_4/3/PLATA_3/ } \\
\text { /CREX/ALLA/5/OLUS*2/ILBOR//PATKA_7/YAZI_1/10/ALTAR } \\
\text { 84//FD8419-126-1-2/RAZZAK/3/KRF-DW/BALADIA HAMRA/9/ALTAR } \\
\text { 84/860137//YAZI_1/4/LIS_8/FILLO_6/3/FUUT//HORA/JOR/8/GEDIZ/FGO// } \\
\text { GTA/3/SRN_1/4/TOTUS/5/ENTE/M }\end{array}$ & 2142 & $17 \times 20$ \\
\hline 23 & $\begin{array}{l}\text { GIZA 165/AZEGHAR-1 /10/CBC509CHILE//SOOTY-9RASCON- } \\
\text { 37/9/USDA595/3/D67.3/RABI//GRA/4/ALO/5/HUI/YAVI/6/ARDENTE/7/ } \\
\text { HUI/YAV79/8/POD-9 }\end{array}$ & 2148 & $26 \times 24$ \\
\hline
\end{tabular}

\section{Scanning Electron Microscopy:}

Scanning the wheat grains through using the surface scan electron microscopy was obtained for the three tetraploid wheat strains and five hexaploid wheat varieties beside the resulted interspecific 6 crosses. The detailed surface scan attribute features were examined by Scanning Electron Microscopy (SEM) using suitable magnification $(100 \mu \mathrm{m})$. The dry grains were mounted on copper stubs and coated with a thin layer of gold palladium in a sputter coater unit, Polaron E5000. Scanning was done on JEOL-JSM $\mathrm{T}(1000)$ Model Scanning Electron Microscope at the central lab of National Research Center, Dokky, Giza. The magnification power was expressed under each SEM photograph. Each sample is represented by three micrographs: a. complete grain (dorsal and ventral view). b. surface scan of epidermal grain coat (surface view) and c. surface scan of the hairy end. The sputter coating procedure: Edwards England S 150 A (*) sputter coating had been used to coat samples with golden layer before being viewed in the SEM that make surface of samples very reflective (Bekhit, 2007).

\section{Cytological studies on interspecific hybrids:}

Young spikes of appropriate size were fixed in Carnoy's fluid for $24 \mathrm{~h}$ before storing in $70 \%$ ethanol at $4{ }^{\circ} \mathrm{C}$. Temporary smears of pollen mother cellss were prepared with $1 \%$ acetocarmine and examined after removing the access of stain in smears with $45 \%$ acetic acid.

\section{Fraibilin with SDS=PAGE electrophoresis analysis:}

\section{Starch Extraction.}

1. Water washing for extracting the starch.

$100 \mathrm{gm}$ of wheat grains were dry crushed in a hand driven roller mill, then steeped overnight at $\leqslant{ }^{\circ} \mathrm{C}$ in water, then gently macerated with a mortar and pestle. The resultant slurry was passed through a $75 \mathrm{pm}$ mesh sieve. This step was repeated until the starch was 
visibly absent from the slurry (about 4-5 maceration steps). The milky starch suspension, which passed through the sieve, was centrifuged at 3,000 $\mathrm{g}$ for 10 minutes and the starch was scraped to remove the brownish protein layer on top of the pellet until the starch was visibly clean. The pellet was then resuspended in water, and the process was repeated until the brownish protein layer disappeared after centrifugation. The starch was then spread on aluminum foil and air dried for 48 hours.

Extraction and Analysis of starch granule protein.

\section{r. Extraction starch granule protein for SDS- PAGE analysis.}

$300 \mathrm{mg}$ of purified starch was extracted with $2 \%$ $(\mathrm{w} / \mathrm{v}) \operatorname{SDS}\left(3 \mathrm{ml}\right.$ for extraction at $\left.20^{\circ} \mathrm{C}\right)$ for 30 minutes in $10 \mathrm{ml}$ centrifuge tubes. The suspensions were then centrifuged at $3,000 \mathrm{~g}$ for 10 minutes and the supernatant was pipetted into a clean centrifuge tube with discarding the residue. Acetone was added (after pre-cooling to $-10{ }^{\circ} \mathrm{C}$ ) to three times the original volume. Freezing the tubes at $-10^{\circ} \mathrm{C}$ overnight to allow the protein to precipitate. The tubes were then centrifuged at 3,000 $\mathrm{g}$ for 15 minutes, the supernatant decanted, and the tubes stored at $-10^{\circ} \mathrm{C}$ until needed.

\section{3 .SDS-PAGE analysis of extracted proteins.}

Starch granule proteins from the eight strains and the resulted crosses of tetraploid and hexaploid wheat were extracted from whole grains and the protein pellet resuspended in sample buffer as described by Laemmli and Favre (1973), $\mathrm{lM}$ Tris- $\mathrm{HCl}$ ( $\mathrm{pH}$ 6.8), $1 \mathrm{M}$ dithiothreitol (DTT), $10 \%$ (w/v) SDS, glycerol and water. Sample buffer $(0.1 \mathrm{ml})$ was added to each sample aliquot of purified protein (obtained before) in a $10 \mathrm{ml}$ centrifuge tube. The sample was placed in boiling water for $5 \mathrm{~min}$ and then centrifuged briefly. An aliquot of the sample $(25 \mu \mathrm{l})$ was loaded onto each lane of a pre-cast polyacrylamide gel. Molecular marker was normally applied to the one outside lane of the gel to act as standard. The gel was run at $50 \mathrm{~mA}$ constant current, $r \cdot \mathrm{W}, 500 \mathrm{~V}$ ) at room temperature for 1.5 hours, before being silver stained according to Morrissey (1981). The gel was placed into a solution of $20 \%(\mathrm{v} / \mathrm{v})$ ethanol / $5 \%(\mathrm{v} / \mathrm{v})$ acetic acid for 30 minutes, and transferred into a solution of $3.4 \mathrm{mM}$ potassium dichromate and $3.2 \mathrm{mM} \quad \mathrm{HNO}_{3}$ for $1 \cdot$ minutes. The gel was then washed three times with distilled water for 10 minutes each step before being placed into $12 \mathrm{mM}$ silver nitrate for $30 \mathrm{~min}$ and rinsed the gel thoroughly. Finally the gel was incubated in $0.28 \mathrm{M}$ sodium carbonate with $0.05 \% \quad(\mathrm{v} / \mathrm{v})$ formaldehyde, repeating this step until an appropriate staining intensity was achieved. Staining was stopped by transferring the gel into a solution of $1 \%(\mathrm{v} / \mathrm{v})$ acetic acid.

The protein molecules were run from the higher molecular weight product to the lower molecular weight product The presence of a product was identified as "1" and the absence was designated as
" $0 "$. In this way, data were scored for all genotypes or hybrids, their protein products and the protein marker. These data matrices were then entered into the NTSYS-pc (Numerical Taxonomy and Multivariate Analysis System), version 2.202 (Applied Biostatistics) program using the program editor. The data were analyzed using the SIMQUAD (Similarity for Qualitative Data) routine to generate Jaccard similarity coefficients. These similarity coefficients were used to construct dendrograms using the unweighted pair group method with arithmetic averages (UPGMA) employing the SAHN (Sequential, Agglomerative, Hierarchied, and Nested clustering) routine from NTSYS-pc. To investigate how the topology of dendrograms depended on the number of polymorphisms used,

\section{Results}

\section{Interspecific hybridization}

\section{Scanning Electron Microscopy:}

Scanning electron microscopy of dry grains revealed morphological details of grain surface structure. Figure 1 revealed that plump grains with heavy hair in strain 9 (female parent) and had smooth surfaces which could be easily distinguished from buckled and wrinkled surfaces of the resulted cross (2135). At the meantime, the male tetraploid wheat parent (strain 20) had bold narrow end (pappus or brush) free from any hairs. The $F_{1}$ was characterized by few hairs at the same pappus area of the grain. Figure 2 revealed that narrow and plump grains with heavy hair in strain 17 (female parent) but not less than the grains of crosses and had smooth surfaces which could be easily distinguished from buckled and wrinkled surfaces of the resulted cross (2142). At the meantime, the male tetraploid wheat parent (strain 20) had bold narrow end free from any hairs. The $F_{1}$ was characterized by few hairs at the end of the grain. Figure 3 showed that plump grains with heavy hair in strain 6 (female parent) and had smooth surfaces which could be easily distinguished from buckled and wrinkled surfaces of the resulted cross (2128). At the meantime, the male tetraploid wheat parent (strain 20) had pappus bold end free from any hairs. The $\mathrm{F}_{1}$ was characterized by few hairs at the end of the grain. Figure 4 showed that plump grains with heavy hair in strain 8 (female parent) and had smooth surfaces which could be easily distinguished from buckled and wrinkled surfaces of the resulted cross (2132). At the meantime, the male tetraploid wheat parent (strain 20) had bold end free from any hairs (brush was absent). The $F_{1}$ was characterized by few hairs at the end of the grain. Figure 5 revealed that plump grains with heavy hair in strain 17 (female parent) and had smooth surfaces which could be easily distinguished from buckled and wrinkled surfaces of the resulted cross (2135). At the meantime, the male tetraploid wheat 
parent (strain 21) had bold end free from any hairs. The $F_{1}$ was characterized by few hairs at the end of the grain. Figure 6 revealed that plump grains with heavy hair in strain 26 (female parent) and had smooth surfaces which could be easily distinguished from buckled and wrinkled surfaces of the resulted cross (2135). At the meantime, the male tetraploid wheat parent (strain 24) had bold end free from any hairs. The $F_{1}$ was characterized by few hairs at the end of the grain. All the produced six crosses were containing hairy ends as an indicator for the inheritance of this character. Probably complete dominance of the gene controlling the brush area in the wheat grain. All the grain surfaces of the studied genotypes revealed reticulate sculpture (Barthlott, 1984 and Loutfy, 1992 and Salama, 2003, Bekhit, 2007and Bdour et al., (2014)).

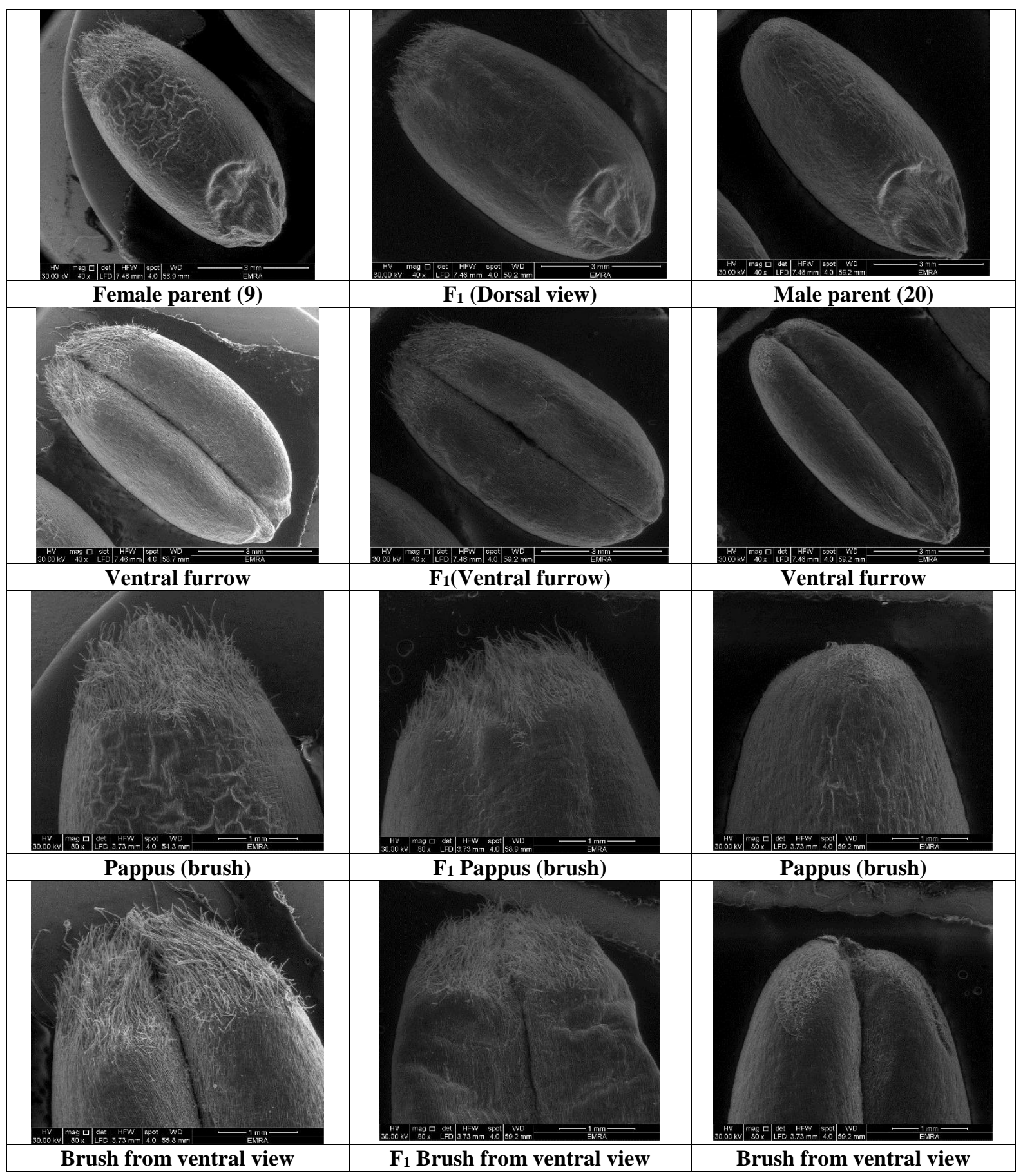

Fig. (1): Surface scan by electron microscopy in hexaploid bread wheat (9) and tetraploid wheat genotype (20) and the resulted $F_{1}(2135)$ show the reticulate sculpture and presence and absence of hairy end. Dorsal and ventral view with focus on the hairy end of the grain. 


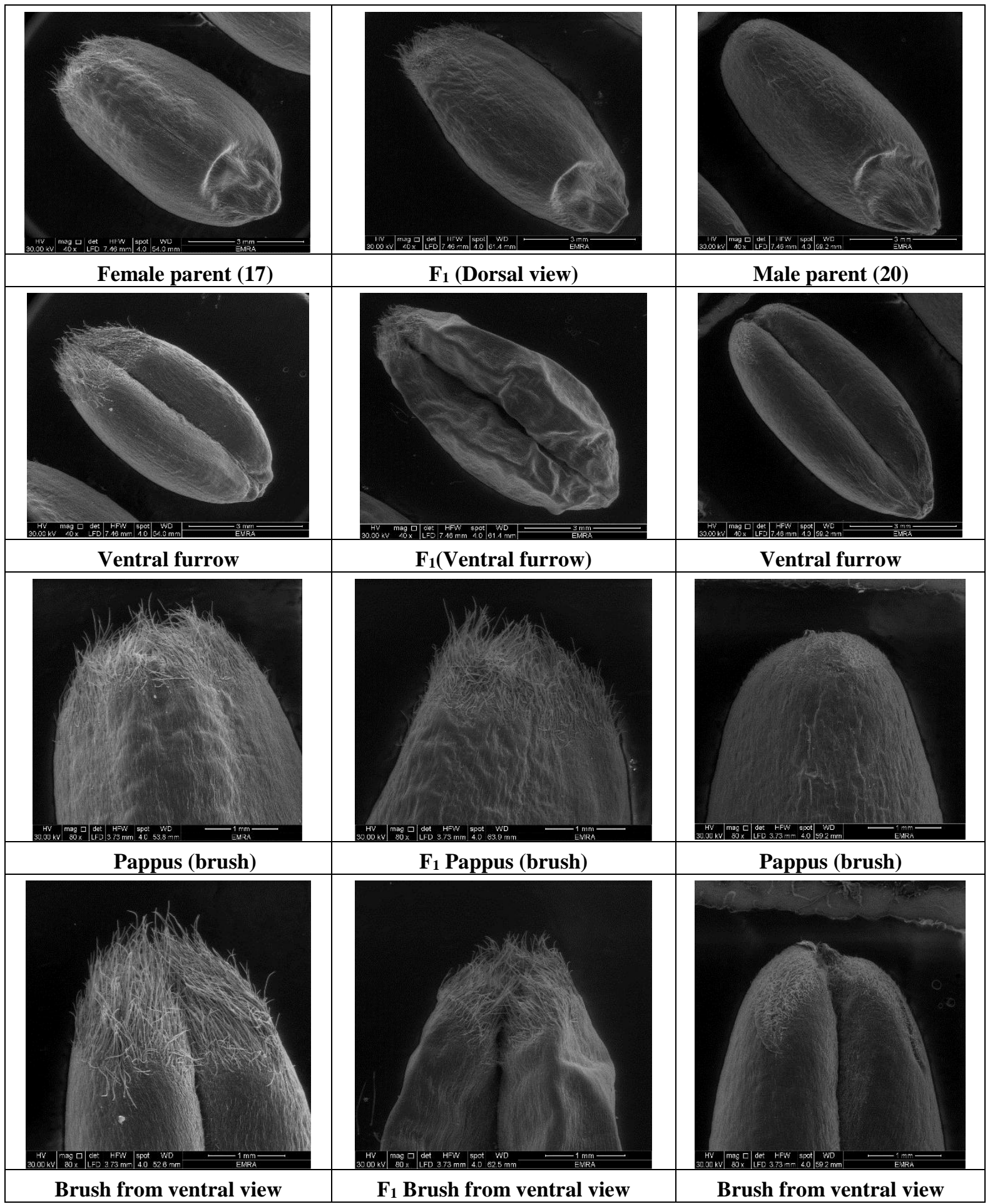

Fig. (2): Surface scan by electron microscopy in hexaploid bread wheat (17) and tetraploid wheat genotype (20) and the resulted $F_{1}(2142)$ show the reticulate sculpture and presence and absence of hairy end. Dorsal and ventral view with focus on the hairy end of the grain. 


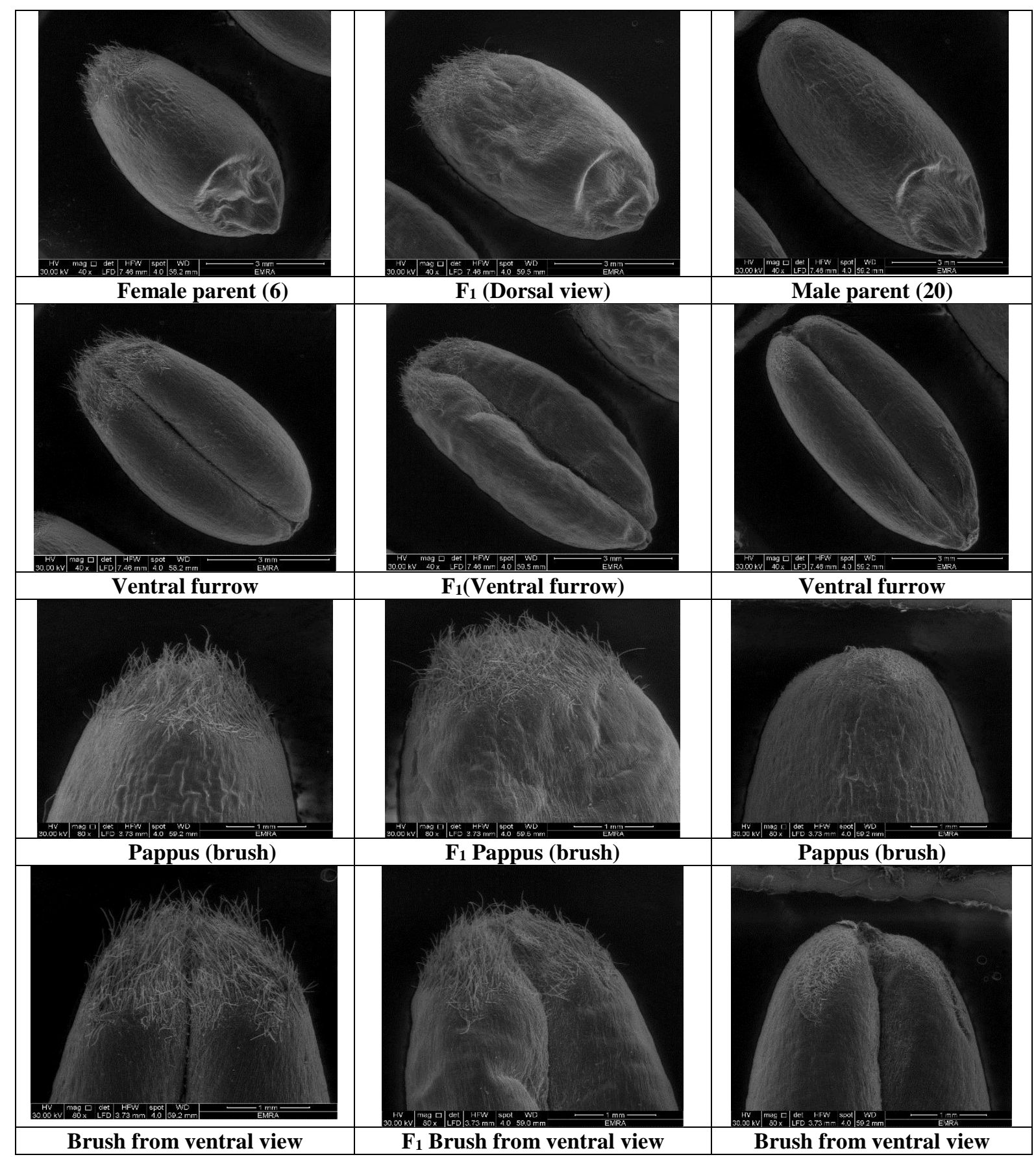

Fig. (3): Surface scan by electron microscopy in hexaploid bread wheat (6) and tetraploid wheat genotype (20) and the resulted $\mathrm{F}_{1}$ (2128) show the reticulate sculpture and presence and absence of hairy end. Dorsal and ventral view with focus on the hairy end of the grain. 


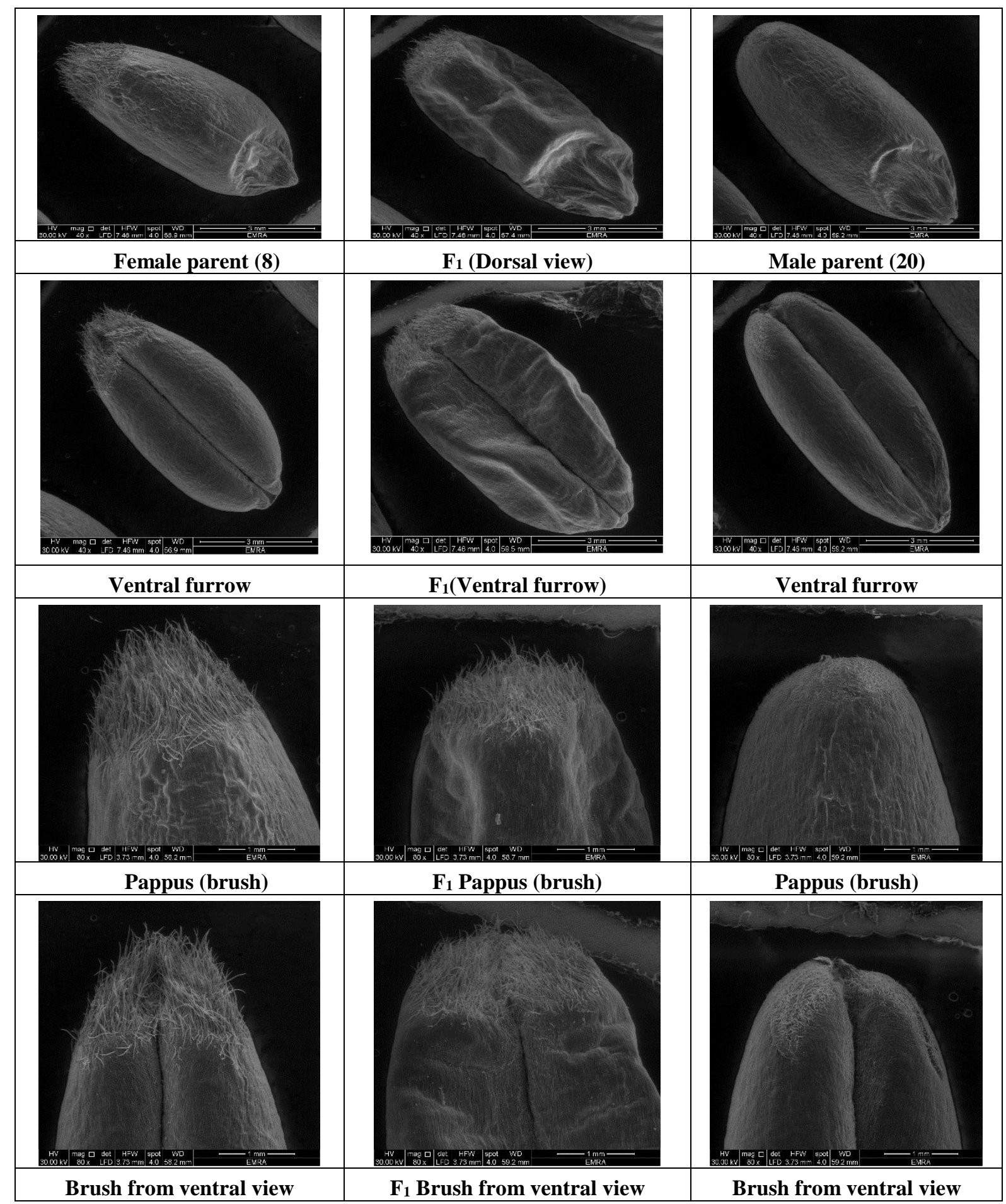

Fig. (4): Surface scan by electron microscopy in hexaploid bread wheat (8) and tetraploid wheat genotype (20) and the resulted $F_{1}$ (2132) show the reticulate sculpture and presence and absence of hairy end. Dorsal and ventral view with focus on the hairy end of the grain. 


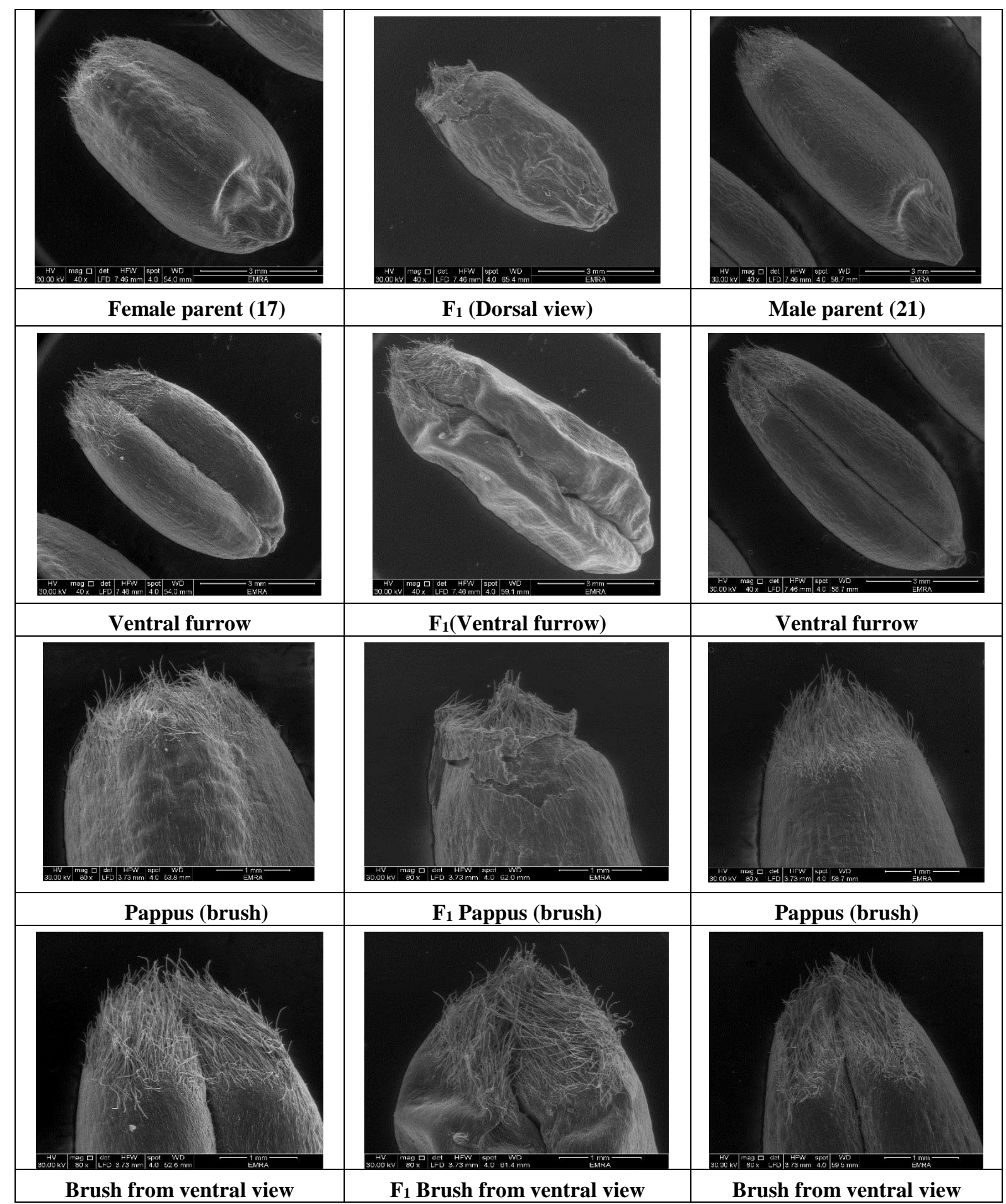

Fig. (5): Surface scan by electron microscopy in hexaploid bread wheat (17) and tetraploid wheat genotype (21) and the resulted $F_{1}(2140)$ show the reticulate sculpture and presence and absence of hairy end. Dorsal and ventral view with focus on the hairy end of the grain. 


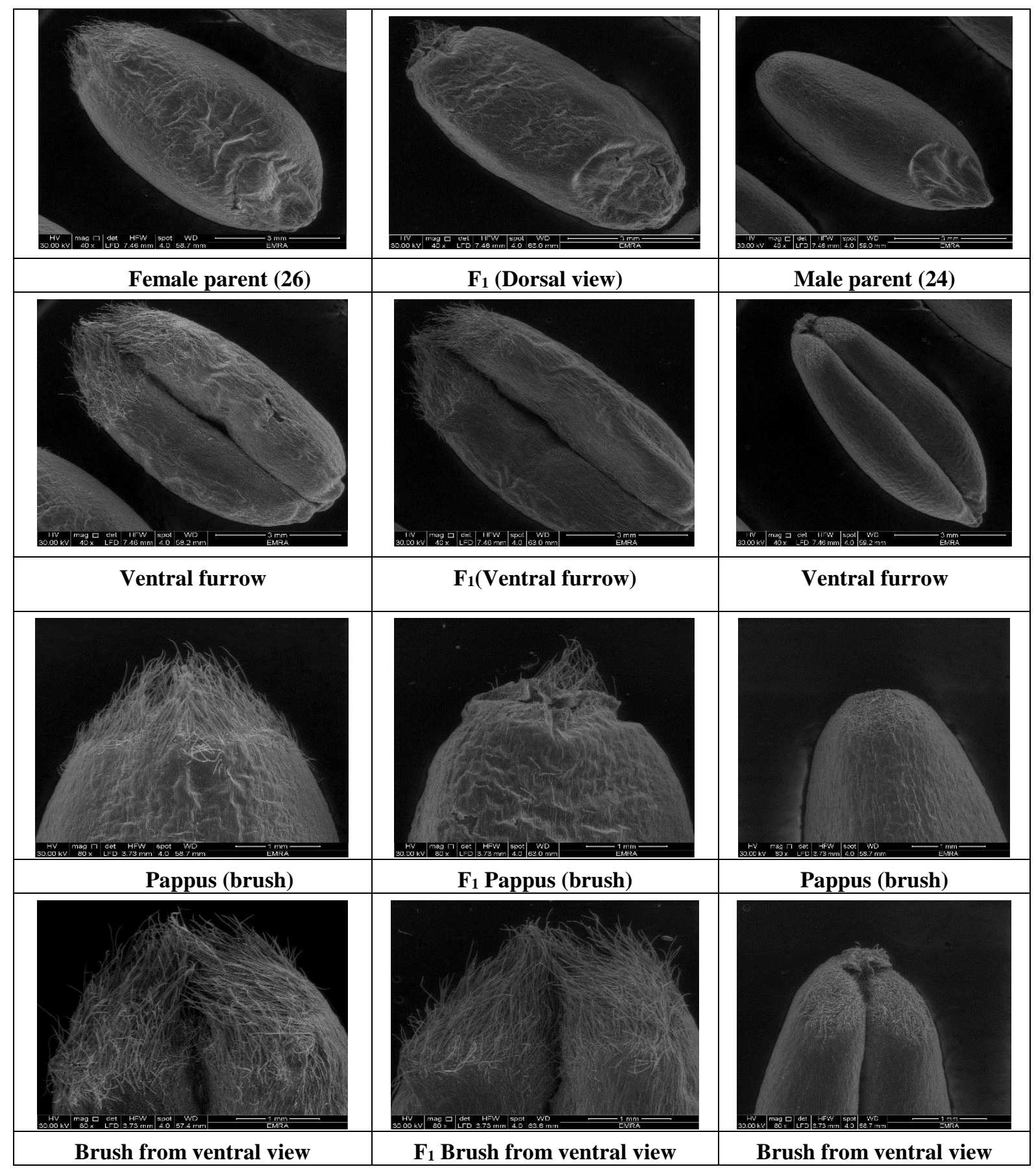

Fig. (6): Surface scan by electron microscopy in hexaploid bread wheat (26) and tetraploid wheat genotype (24) and the resulted $F_{1}(2148)$ show the reticulate sculpture and presence and absence of hairy end. Dorsal and ventral view with focus on the hairy end of the grain.

\section{Meiotic behavior of interspecific hybrids}

The estimates of metaphase I chromosomes revealed a low level of their bivalent pairing in all hybrids and showed high levels in the parental strains (Table 2). The numbers of chromosomes shared in the bivalents ranged from $44.70 \%$ in the 2128 hybrid to $67.43 \%$ in the 2135 hybrid. The number of pollen mother cells (PMCs) in parents with bivalent pairing varied from $96.88 \%$ (strain 6) to $99.50 \%$ (strain 17).
Ring bivalents were detected in all the examined strains more than rod bivalents indicated high percentage of homolog synapsis. Generally, metaphase I is famous by the strict orientation of the centromeres of bivalents (paired chromosomes). The oriented bivalents found in the equatorial line of the pollen mother cell which form the metaphase plate. Univalent chromosomes are the aberrations usually found in this meiotic stage. The maximum number of univalents found in the examined hybrids was seven 
(Figure, 7, 8 and 9). If we considered that the univalents which found in metaphase I are the main source of aberrations in the next stages of meiosis, The aberrations which expected to appear in anaphase I in the obtained 6 interspecific hybrids are laggards and bridges. One of the main aberrations in the examined crosses in anaphase I was the lag of one or several chromosomes (especially those which found in the univalent state in metaphase I, Figure, 7, 8 and 9). The univalents are scattered in the area of the metaphase equator of the PMC in anaphase I. Most lagging univalents fail to move toward the poles, remain in cytoplasm, and finally form micronuclei in the dyad cells in the telophase (Figure, 7, 8 and 9). The number of lagging chromosomes in PMCs with aberrations ranged from one to seven. Moreover, PMCs with chromosome bridges were noted in all the six interspecific crosses with number of cells ranged from 190 in the cross (2142) to 94 in the cross (2148). The percentages of PMCs without aberrations in anaphase I varied from 40.08 in the cross (2148) to $67.30 \%$ in the cross (2135). If we compare the number of aberrations in anaphase I with that in metaphase II, it revealed that an increase in all the six interspecific crosses. The most detected aberration in this stage, as in metaphase I, was the presence of chromosomes outside the metaphase equator (Figure 7, 8 and 9). The numbers of these chromosomes in the examined crosses ranged from one to five. Asynchronous division was detected in the examined PNC,s. Their numbers were variable from 5 in the cross 2148 to 206 in the cross 2128. The percentages of PMCs free from aberrations in metaphase II were ranged from 52.90 in the cross 2140 to $67.95 \%$ in the cross (2148). (Table 2). Also in anaphase II, chromosomal disjunction to poles was accompanied by the lag of some chromosomes, asynchrony and bridge formation (Figures, 7, 8 and 9). It was found that, the numbers of lagging chromosomes in anaphase II were nearly the same as in the previous stage, ranging from one to five. Tetrads are the final stage, the main aberration at this stage was the presence of micronuclei. Their numbers in the studied crosses ranged from one to four. Tetrads usually one or two micronuclei are formed (Figures 7, 8 and 9). Therefore, the meiotic instability found in all the obtained six interspecific crosses ensures the formation of viable gametes needs five to six succeeding generations (Orlovskaya, et al 2016).

Table 2. Meiotic stages in the obtained interspecific hybrids and their parents.

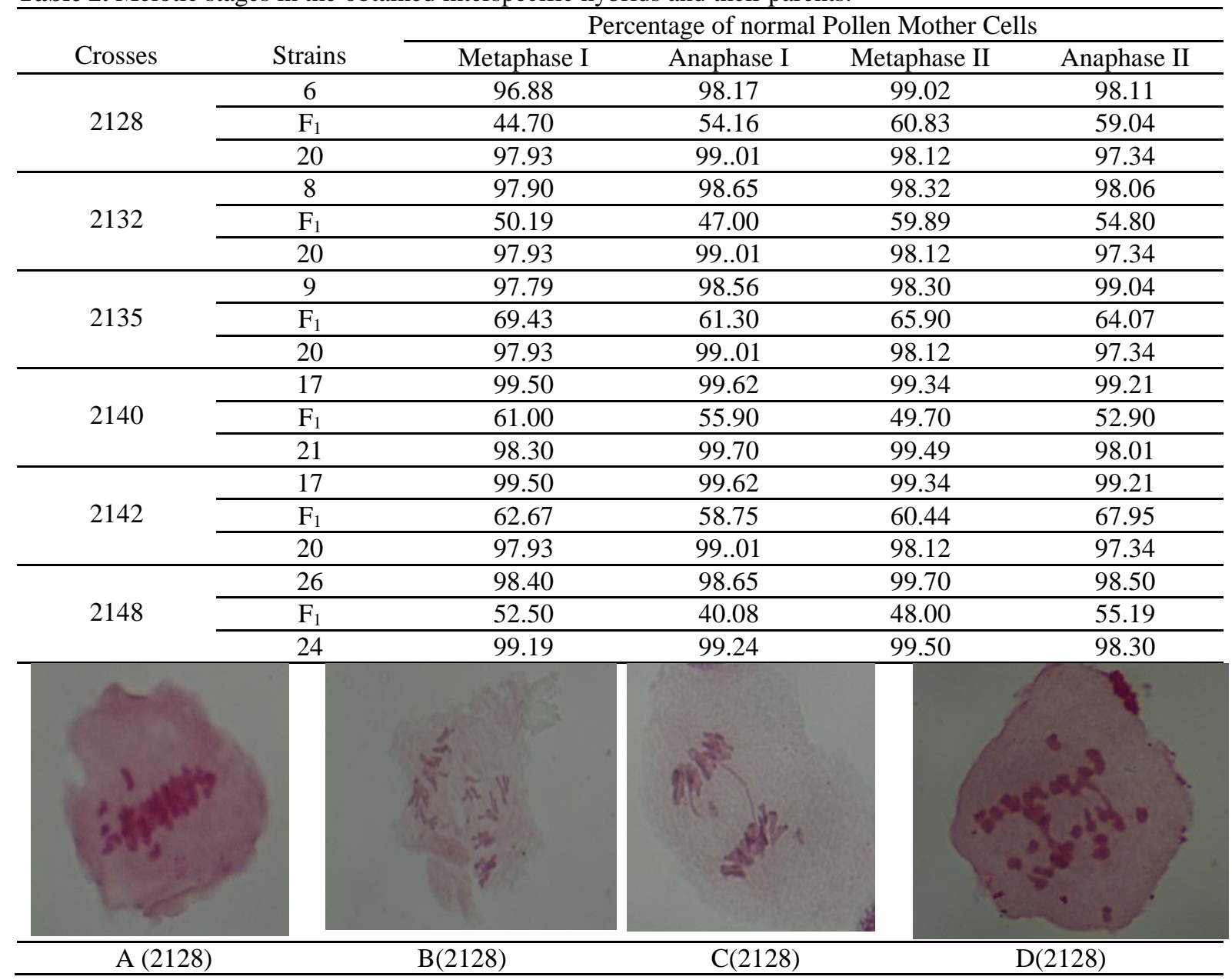




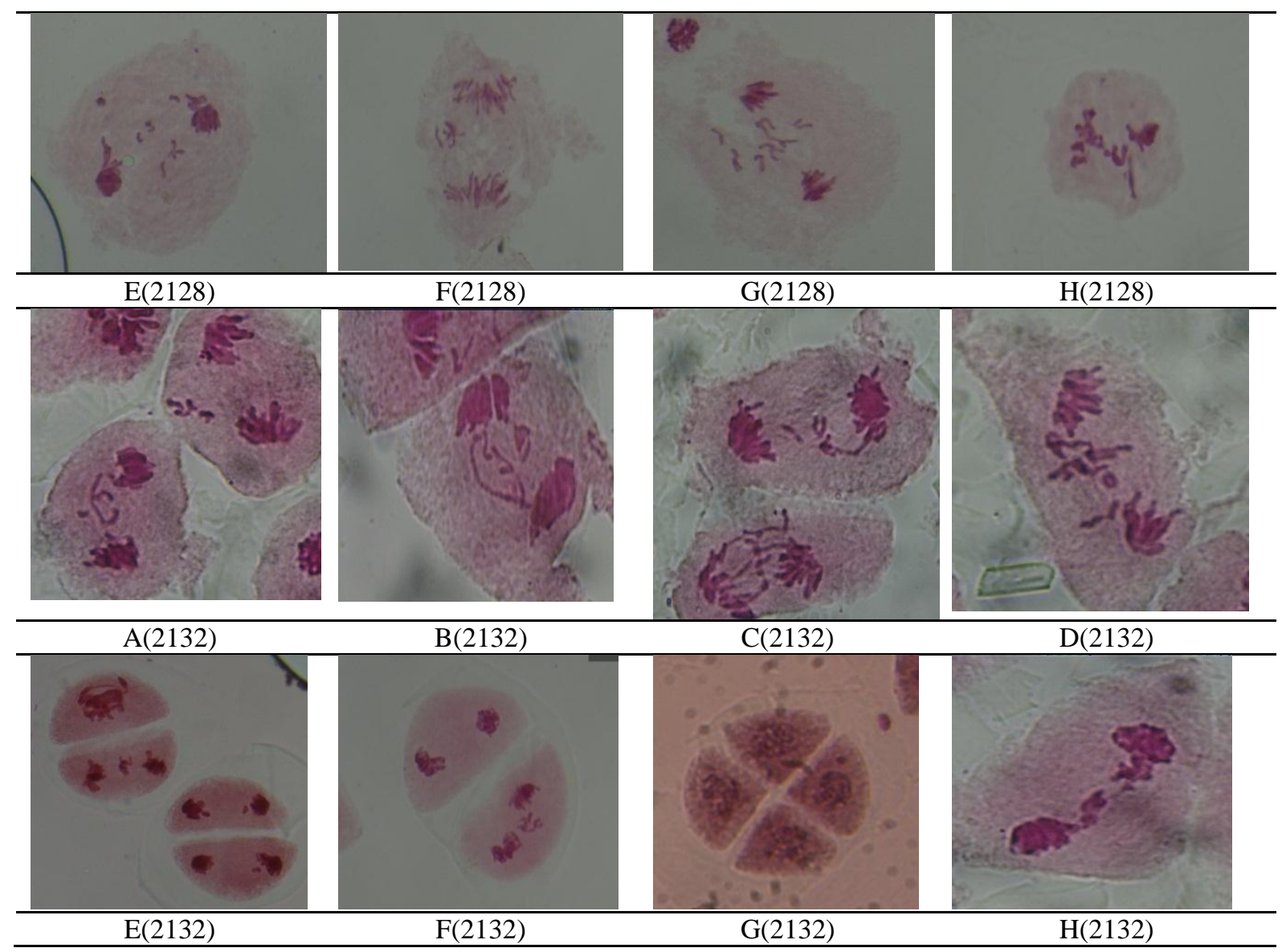

Figure 7. Show meiotic behavior in pollen mother cells of the hybrid 2128. Figures (a-h. a) metaphase I and anaphase I with rod chromosomes (x600) ; b, C and D) anaphase (x600); Abnormal separation of sister chromatids moved toward opposite poles with laggards and bridge formation.. Figures (a-h) for $2132 \mathrm{e}$ ) dyad of microspores showing a binuclate microspore and the other one with a restitutional nucleus (14 II, x600); f) anaphase I - normal separation (x600); g) Tetrad with a micronucleus (x600); H) chromosome restitution at telophase I.

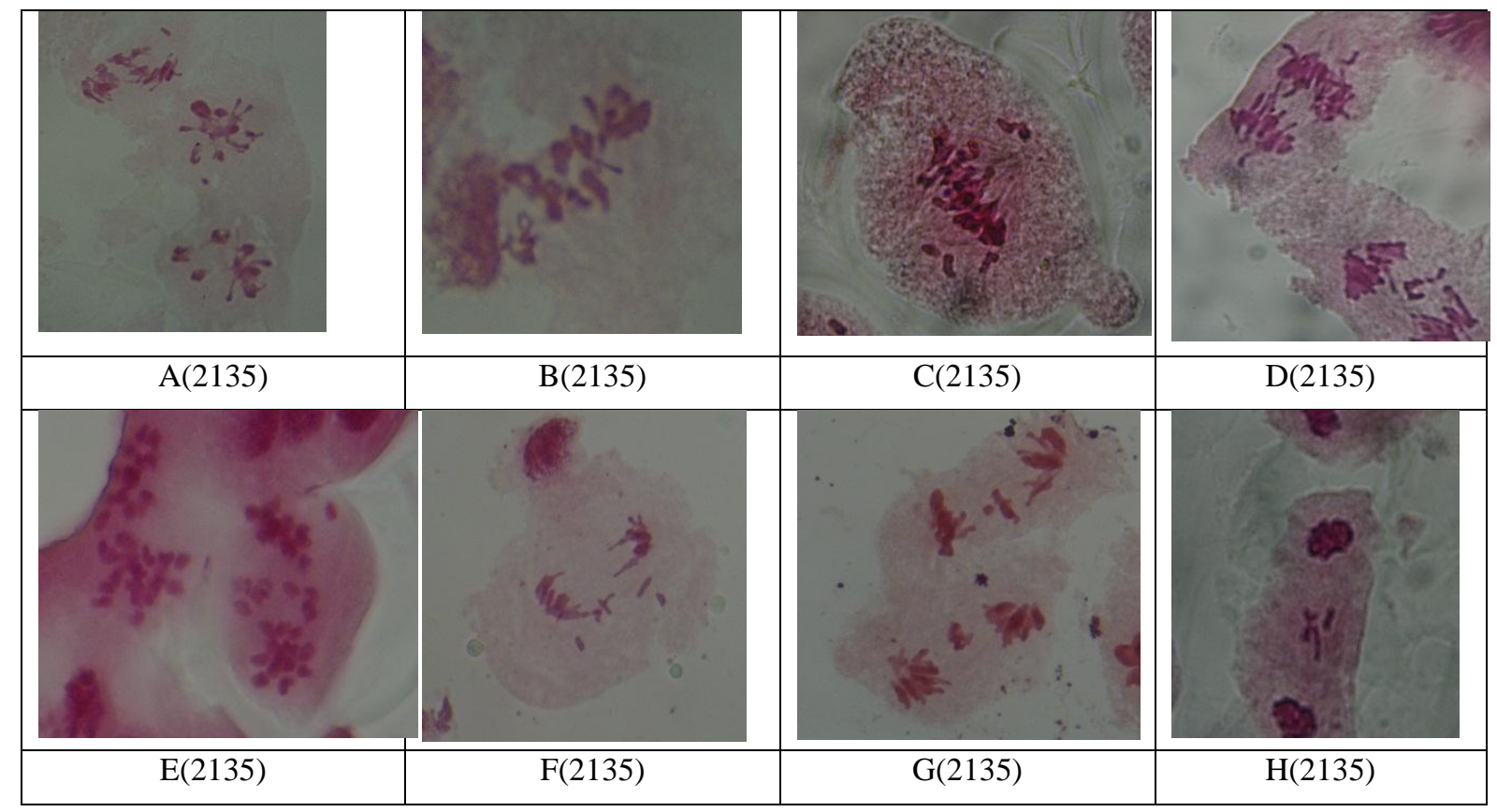




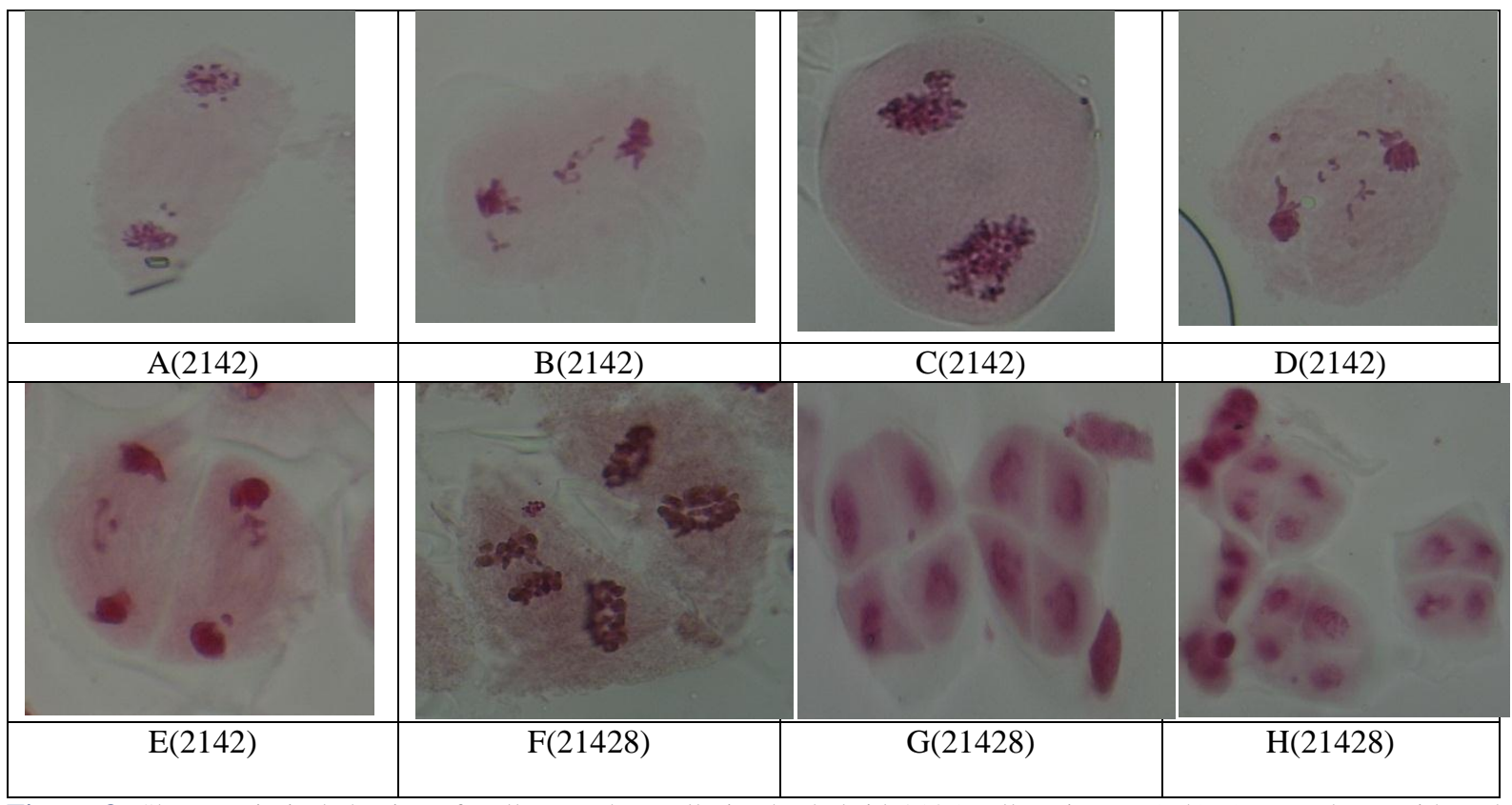

Figure 8. Show meiotic behavior of pollen mother cells in the hybrid 2135 cells. Figures (a-h) a) metaphase with rod chromosomes (x600); b) anaphase I - bridge formation (x600); c) lagging chromosome in anaphase I (x600); F) multipolar separations. Figures (a-h) hybrid 2142 e) diakinesis (14 II, x600); f) anaphase I - normal separation (x600); g) anaphase I - laggards (x600). G and H Tetrads with micronuclei formation.

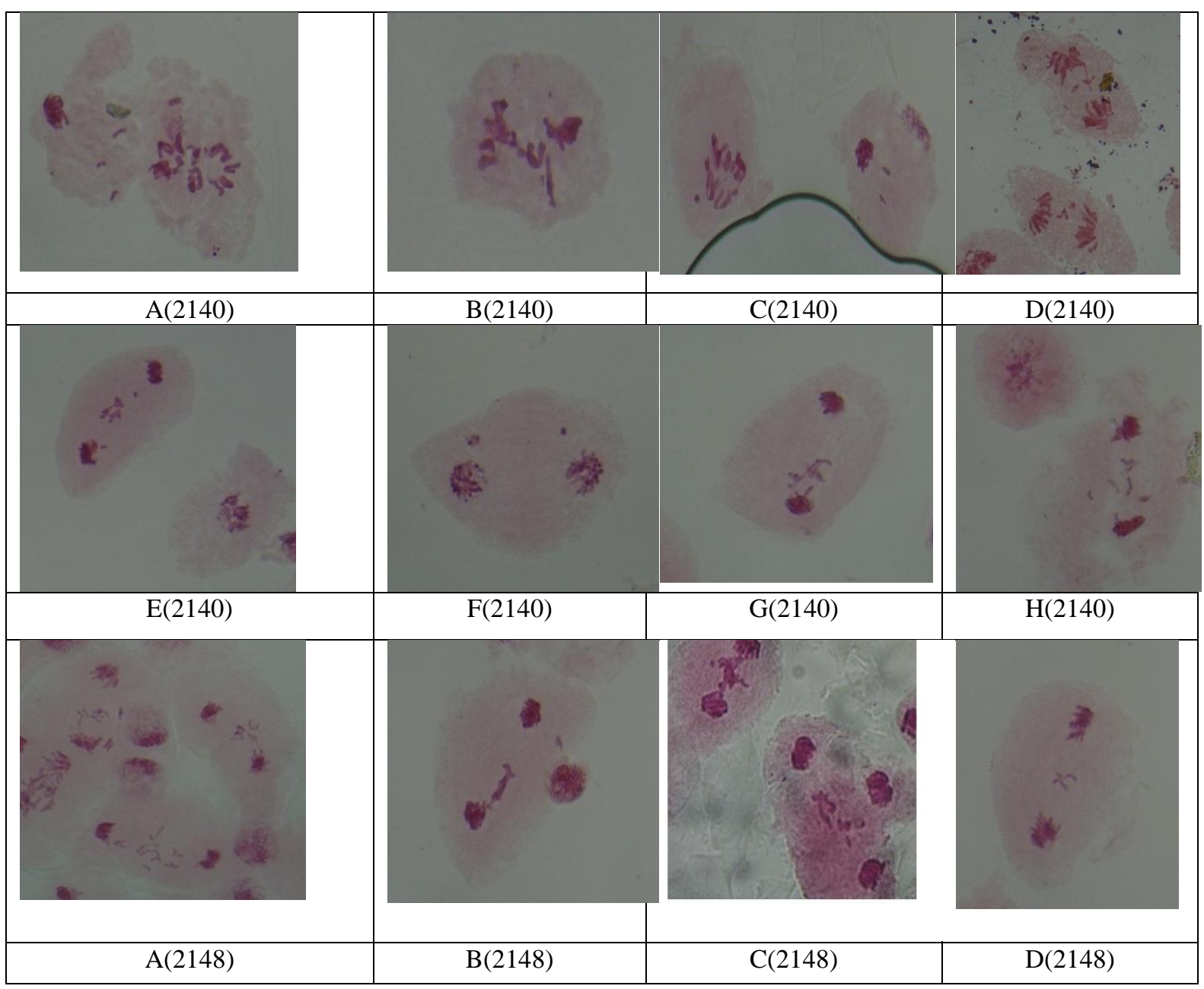




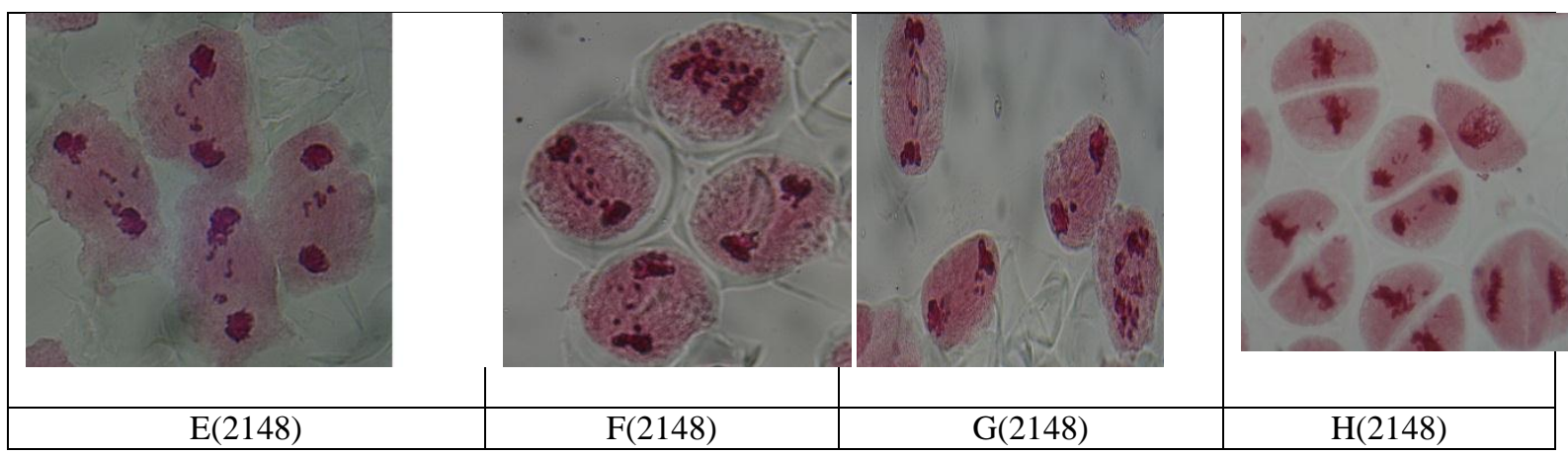

Figure 9. Show meiotic behavior of pollen mother cells. Figures (a-h) for the hybrid 2140 cells. a) metaphase with rod chromosomes (x600); b) anaphase I - bridge formation (x600); c) anaphase I - laggards (x600); Figures (a-h) for the hybrid 2148 e) diakinesis (14 II, x600); f) anaphase I - normal separation (x600); g) anaphase I - laggards (x600);

Figure (7) revealed that the behavior of pollen mother cells during meiosis reflects the cytological behavior of interspecific hybrid (2128) as a result of crossing between $T$. durum with T. aestivum. Figures (a-d) show meiotic behavior of pollen mother cells in the hybrid 2128. a) Metaphase I with Telophase I with 7 lagging chromosomes. ; b) metaphase II with 2 lagging chromosomes. Telophase II with lagging between two poles of chromosomes. 5 laggards at anaphase I ; one bridge formed at anaphase I.;

c) metaphase I and anaphase I with laggards. in the pollen mother cells during meiosis in interspecific hybrid (2132) as a result of crossing between $T$. durum with T. aestivum. Figures (a-d) show meiotic behavior of pollen mother cells in the hybrid 2132 as Telophase I with lagging chromosomes or bridges.

Figure (8) showed that the behavior of pollen mother cells during meiosis revealed the cytological behavior of interspecific hybrid (2135) as a result of crossing between $T$. durum with T. aestivum. Figures (a-d) show meiotic behavior of pollen mother cells in the hybrid 2135. a) Telophase I with 2 lagging chromosomes. ; b) Tetrad at meiosis with micronuclei. Anaphase I and Telophase I with lagging between two poles of chromosomes. c) metaphase I and anaphase I with laggards. in the pollen mother cells during meiosis in interspecific hybrid (2142) as a result of crossing between T. durum with T. aestivum. Figures (a-d) show meiotic behavior of pollen mother cells in the hybrid 2142 as metaphase I and telophase I with lagging chromosomes or bridges.

Figure (9) found that the behavior of pollen mother cells during meiosis showed the cytological behavior of interspecific hybrid (2140) as a result of crossing between $T$. durum with T. aestivum. Figures (a-d) show meiotic behavior of pollen mother cells in the hybrid 2140. a) Telophase I with 2 lagging chromosomes. ; b) Tetrad at meiosis with micronuclei. Anaphase I and Telophase I with lagging between two poles of chromosomes.

c) metaphase I and anaphase I with laggards. in the pollen mother cells during meiosis in interspecific hybrid (2148) as a result of crossing between T. durum with T. aestivum. Figures (a-d) show meiotic behavior of pollen mother cells in the hybrid 2148 as metaphase I and telophase I with lagging chromosomes or bridges.

Table 3. Chromosomal abnormalities in 6 interspecific crosses of tetraploid and hexaploid wheat strains.

\begin{tabular}{ccccccccc}
\hline \multirow{2}{*}{$\begin{array}{c}\text { S. } \\
\text { No. }\end{array}$} & Crosses & $\begin{array}{c}\text { No. of } \\
\text { PMC's } \\
\text { analyzed }\end{array}$ & $\begin{array}{c}\text { Cho. of Cells with Abnormal stages (Percent Values) } \\
\text { stickiness }\end{array}$ & $\begin{array}{c}\text { Precocious } \\
\text { migration }\end{array}$ & $\begin{array}{c}\text { Anaphase } \\
\text { bridges }\end{array}$ & Laggards & Micronucleus & $\begin{array}{c}\text { Chromosome } \\
\text { disintegration }\end{array}$ \\
\hline 1 & 2128 & 923 & 133 & 19 & 118 & 379 & 206 & 54 \\
\hline 2 & 2132 & 432 & 37 & 27 & 95 & 224 & 30 & 19 \\
\hline 3 & 2135 & 595 & 121 & 50 & 143 & 204 & 60 & 17 \\
\hline 4 & 2140 & 837 & 168 & 28 & 175 & 316 & 83 & 67 \\
\hline 5 & 2142 & 711 & 189 & 47 & 190 & 234 & 31 & 20 \\
\hline 6 & 2148 & 258 & 78 & 11 & 94 & 62 & 5 & 6 \\
\hline
\end{tabular}

\section{Cytology of interspecific hybrids}

T. monococcum (diploid einkorn wheat,) was the donor of A genome to the cultivated wheat (Sears 1948). It harbours many genes conferring resistance against many diseases (Cadle et al. 1997; Gill et al. 1988; Hussien et al., 1998; McIntosh et al. 1984; Miranda et al., 2007) high protein content (Vallega
1978) and adaptability to wide environments. The cultivated and wild forms of T. durum are known to provide disease resistance genes (Dyke 1992; Perugini et al. 2008). In the present study, pollen mother cells cytology revealed meiotic abnormalities exhibiting chaotic chromosome pairing culminating in abnormal chromosome separation and predisposed laggard formation (Fig. 7, 8 and 9), caused by 
genomic imbalances between the species. The multivalent formation suggested a homeological relationship between these species. These meiotic anomalies resulted in the formation of anomalous pollen precursor cells, resulting in polymorphic sterile pollen grains. Similar results were obtained by Arzani and Poursiahbidi (2015); Arzani and Saeidi (2010); Chen and Zhang (1991); Fukuda and Sakamoto (1992); Jauhar, et al., (2004); Li and Liu (1993); Merker and Tesemma (1994); Sheibanirad, et al.,
(2014); Sini, Fatemeh and Arzani (2015); Thomas, et al., (1998); Tomar and Vari (1995) and Wang et al., (2005).

\section{Friabilin with SDS=PAGE electrophoresis} analysis:

Friabilin, a low molecular weight starch granule protein thought to be associated with differences in endosperm texture was investigated.

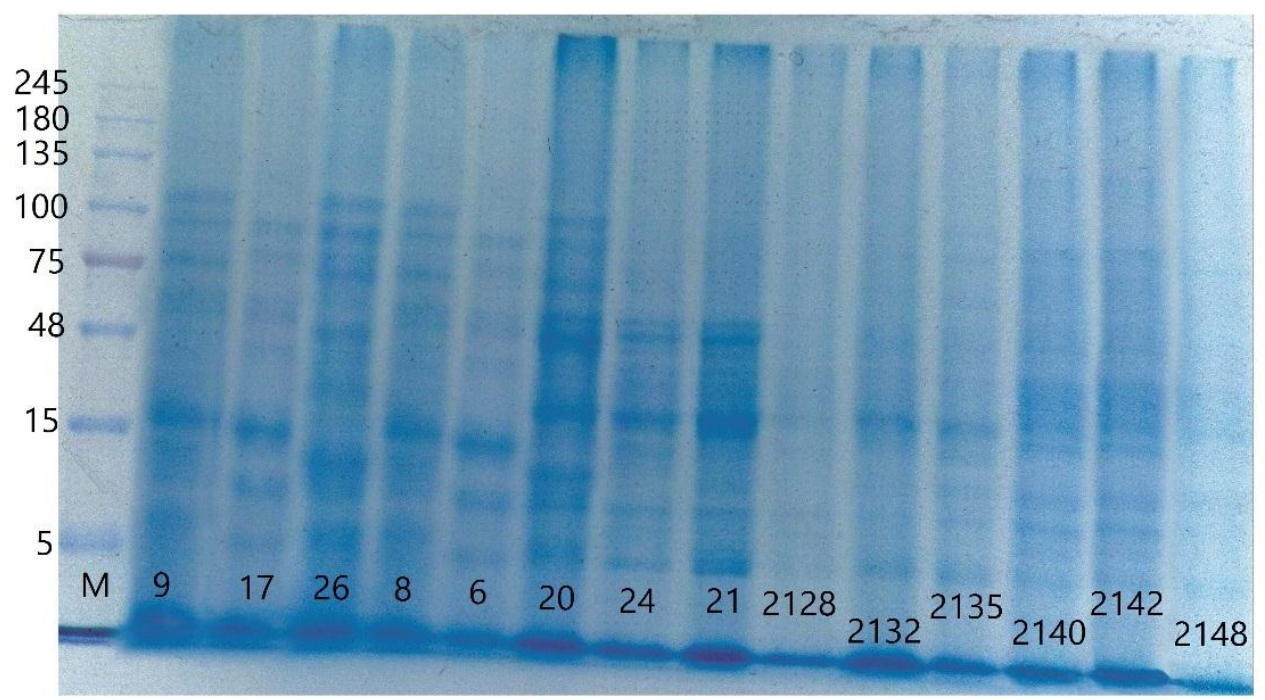

Fig. (10). Characterization of SGP (starch granule proteins) on hard and soft wheat starches. Varieties 6, 8, 9, 17,26, 20, 21 and 24 beside 6 crosses between hard and soft wheat illustrating defined electrophoretic bands of $M_{\mathrm{r}} 15,30,45,59$, 76 and 95,000 as separated by SDS treatment.

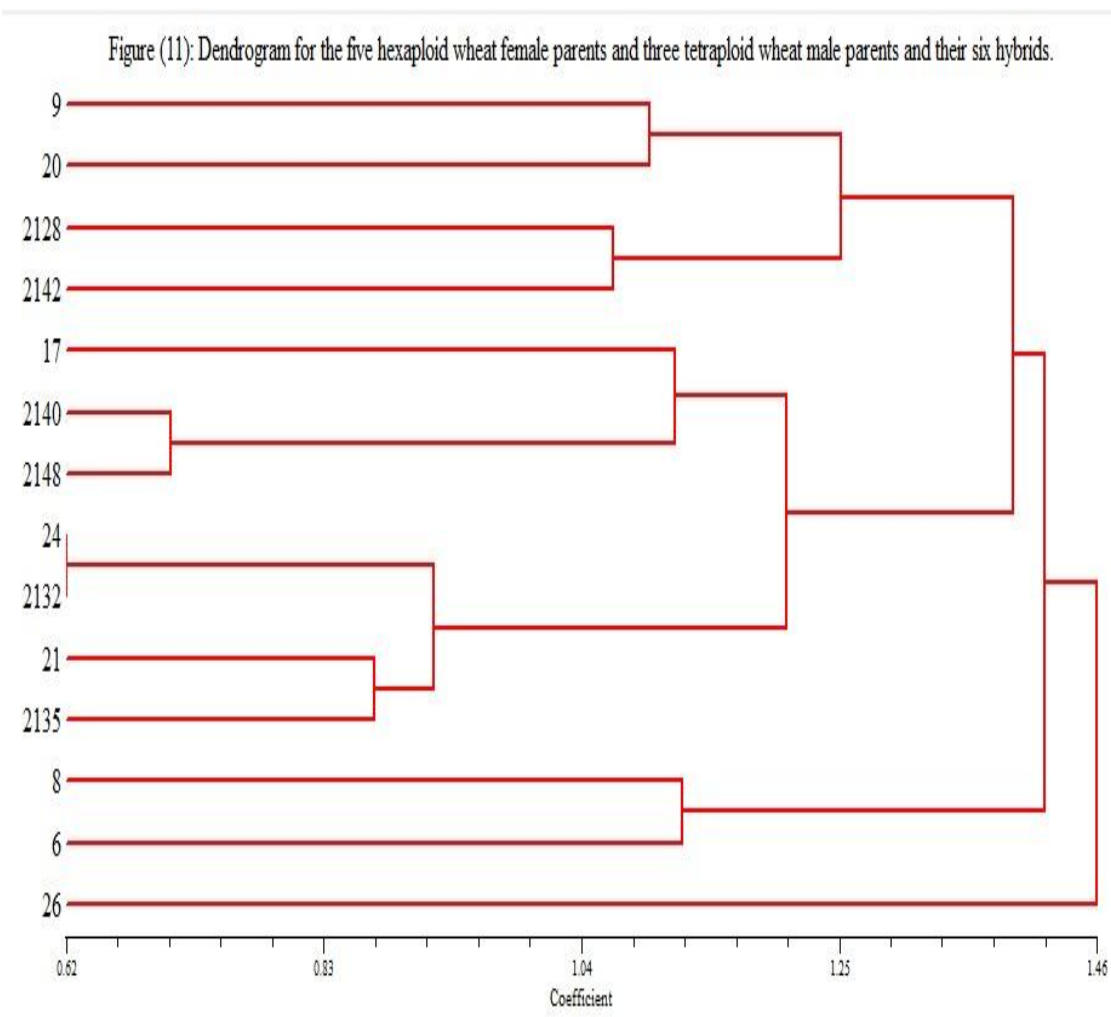


Table 4. Similarity index (Pairwise comparison) among the five wheat hexaploid strains, three tetraploid strains and their $\mathrm{F}_{1}$ (Six crosses) based on SDS-protein (Friabilin) analysis.

\begin{tabular}{|c|c|c|c|c|c|c|c|c|c|c|c|c|c|c|}
\hline & 9 & 17 & 26 & 8 & 6 & 20 & 24 & 21 & 2128 & 2132 & 2135 & 2140 & 2142 & 2148 \\
\hline 9 & 1 & & & & & & & & & & & & & \\
\hline 17 & 0.36 & 1 & & & & & & & & & & & & \\
\hline 26 & 0.15 & 0.00 & 1 & & & & & & & & & & & \\
\hline 8 & 0.17 & 0.36 & 0.31 & 1 & & & & & & & & & & \\
\hline 6 & 0.17 & 0.18 & 0.15 & 0.17 & 1 & & & & & & & & & \\
\hline 20 & 0.53 & 0.43 & $\mathbf{0 . 0 0}$ & 0.13 & 0.27 & 1 & & & & & & & & \\
\hline 24 & 0.00 & 0.25 & $\mathbf{0 . 0 0}$ & 0,22 & 0.22 & $\mathbf{0 . 3 3}$ & 1 & & & & & & & \\
\hline 21 & 0.20 & 0.22 & 0.00 & 0.20 & 0.00 & 0.31 & 0.57 & 1 & & & & & & \\
\hline 2128 & 0.29 & 0.00 & $\mathbf{0 . 0 0}$ & $\mathbf{0 . 0 0}$ & 0.00 & 0.20 & 0.00 & 0.00 & 1 & & & & & \\
\hline 2132 & 0.00 & 0.29 & 0.00 & 0.25 & 0.00 & 0.18 & 0.80 & 0.67 & 0.00 & 1 & & & & \\
\hline 2135 & 0.18 & 0.40 & 0.17 & 0.18 & 0.00 & 0.14 & 0.50 & 0.67 & 0.00 & 0.57 & 1 & & & \\
\hline 2140 & 0.17 & 0.55 & 0.46 & 0.17 & 0.17 & 0.13 & 0.22 & 0.20 & 0.00 & 0.25 & 0.55 & 1 & & \\
\hline 2142 & 0.50 & 0.36 & 0.15 & 0.00 & 0.33 & 0.27 & 0.00 & 0.20 & 0.29 & 0.00 & 0.36 & 0.50 & 1 & \\
\hline 2148 & 0.00 & 0.50 & 0.20 & 0.22 & 0.00 & 0.00 & 0.33 & 0.29 & 0.00 & 0.40 & 0.50 & 0.67 & 0.44 & 1 \\
\hline
\end{tabular}

The electrophoretic banding patterns of proteins extracted from the leaves of the five hexaploid wheat strains, three tetraploid wheat strains and the six hybrids between these strains are shown in Figure (10). The presence and absence of bands were represented with (1) and (0), respectively. The results of SDS-PAGE revealed a total number of 68 bands with molecular weights (MW) ranging from about 5 $\mathrm{kDa}$ to $100 \mathrm{kDa}$, which were not necessarily present in the 14 genotypes. Data revealed no common bands (monomorphic), while the remaining 18 band were polymorphic with $100 \%$ polymorphism. The densitometric analysis of the SDS-protein banding patterns of the studied genotypes were found to be useful in varietals identification of the studied wheat genotypes. The parental eight genotypes revealed different patterns in presence of bands. The maximum number of bands (7) appeared in strain (26) while the minimum number (1) was present in the resulted cross (2128). The unique band at $25 \mathrm{KR}$ is the characteristic band for the strain 6. Moreover, the unique band at 67 $\mathrm{KR}$ is the only band for the strain 26 . The unique band at the $82 \mathrm{KR}$ is the distinguishable band for the strain 26 and strain 8 . The unique band at the $59 \mathrm{KR}$ is the distinguishable band for the strain 8 and strain 6 . The unique band at the $54 \mathrm{KR}$ is the distinguishable band for the strain 9 and strain 20. The unique band at the $48 \mathrm{KR}$ is the distinguishable band for the strain 9 and strain 20. The unique band at the $11 \mathrm{KR}$ is the distinguishable band for the strain 6 and the hybrid 2142. The indicator band for the presence of Friabilin was found at $15 \mathrm{KR}$ in the strains; 17, 8, 24, 21, and the $F_{1}$ hybrids; 2132, 2135, 2140 and 2148, respectively. The other indicator band for the presence of Friabilin was found at $17 \mathrm{KR}$ in the strains; 9, 20, and the $F_{1}$ hybrids; 2128 and 2142, respectively. Moreover, there is an indicator band for Friabilin at 30 $\mathrm{Kr}$ was found in the strains; 20, 24 and 21 beside the $\mathrm{F}_{1}$ crosses; 2132 and 2135, respectively. However, there are resemblance between most of the studied genotypes in the band at the $5 \mathrm{KR}$ except the strain 17 and the F1 hybrids; 2128 and 2132, respectively, so it considered as a unique fingerprint. SDS-PAGE analysis has shown that there are at least ten polypeptides that compose SGP, of which five (ranging from Mr 5-30,000) appear to be associated with the surface of the starch granule, and five associated with the integral structure of the granule (Mr 45-149,000), the differentiation between surface and integral being based on the ease of extractability with SDS and the electrophoretic motilities of the polypeptides (Greenwell and Schofield, 1986, Mikulikova 2007 and Pasha et al., 2009).

Wheat hardness as the force required to deform the grain and the resistance of the grain to this deformation. The manner in which fracture occurs, and thereafter fragment size and sifting behavior of the flour, depends upon kernel hardness. Thus, a hard wheat requires more force to fracture the kernel than a softer one, and is regarded as having strong adhesion between the starch and protein in the endosperm Greenway (1969) and MacRitchie (1980). Fragmentation of the endosperm consequently occurs along the lines of the cell boundaries producing coarse, free-flowing flour. Soft wheats have low adhesion between the starch and the protein, and thus the endosperm fractures at the starch granule-protein matrix interface producing a 'sticky' flour with a wide distribution of particle sizes. This, in turn, means that the flours are more difficult to sieve. The relationship between fracture patterns and starch granule damage during milling obviously has effects on the bread making process. The more cohesive nature of the endosperm in hard wheats means that the forces applied to the grain during milling are transferred to the starch granules more efficiently than in soft wheats, resulting in greater levels of mechanical damage to the starch granules. This has implications for the availability of substrates for

yeast fermentation during dough processing, especially for traditional long or bulk fermentation bread making procedures, since mechanically 
damaged starch is much more susceptible to aamylase attack than undamaged granules .Another important effect of starch damage is on the water absorption of the flour and the effects this has on the eventual dough rheology and on bread yield. Damaged starch absorbs more water than undamaged starch necessitating the addition of more water to flours with high levels of starch damage, compared with those with lower levels of starch damage, in order to maintain consistency in the dough profile (Morris and Massa (2003); Morris, et al., (2001); Rahman et al., (1994); Turnbull and Rahman (2002) and Tranquilli et al., (2002). Higher starch damage levels are desirable in bread flours because of its effects on dough rheology and bread yield (through the increased requirement for additional water) but undesirable in biscuit flours where the rheological effects are detrimental to product quality and where the higher water requirement results in high energy costs during baking. Thus, the endosperm texture of wheats has important effects as to the end-use of a particular cultivar (Giacintucci et al., (2014); Igrejas, et al., (2001 and 2002); Giroux et al., (1998); Giroux, et al., (2000); Greenblatt, et al., (1995); Huebner and Gaines (1992); Hogg et al., (2005); See et al., (2004); Swan et al., (2006). Law et al., (1978) examined different types of genetical lines of wheat (single chromosome substitution lines of a single wheat containing chromosomes from a hard wheat, and recombinant lines from a cross between a soft wheat and its single chromosome substitution line containing the 5D chromosome from hard wheats). They found that lines containing the $5 \mathrm{D}$ chromosome were of a soft endosperm texture, whereas those without the 5D chromosome were of a hard endosperm texture. It was therefore proposed that the controlling gene for endosperm texture was located on chromosome 5D and this was termed the hardness' (Ha/ha) gene, with softness being the dominant trait. Similar results are reported by Giroux and Morris (1997). Similar results were obtained by Anjum and Walker (2006); Gaines et al., (2000); Dubreil et al., (1998); Day et al., (2006); Csoti et al., (2005); Charnet et al., (2004); Cane et al., (2004).

\section{References}

Anjum F. M. and Walker C. E. (2006): Review on the significance of starch and protein to wheat kernel hardness. Journal of the Science of Food and Agriculture, 56: 1-13.

Arzani, M. A. A. and Poursiahbidi, M. M. (2015): Meiotic instability in Aegilops cylindrica: a comparison Fatemeh with stable meiosis in Triticum monococcum subsp. Aegilopoides. Caryologia International Journal of Cytology, Cytosystematics and Cytogenetics Volume 68, 2015 - Issue 2 Pages 101-108.
Arzani, M. A. A. and Saeidi, G. (2010): Meiotic Behavior of Wild, Synthetic and Cultivated Wheats. Cytologia 75(2): 169-175.

Barthlott, W. (1984):Microstructural features of seed surfaces. In (concept in plant taxonomy). (ed. V. H. Heywood and D. M. Moore), pp. 95, Academic Press, London.

Bdour, M. A.; Al-Rabadi, G. J.; Al-Ameiri, N. S.; Mahadeen, A. Y. and Aaludatt, M. H. (2014): Microscopic Analysis of Extruded and Pelleted Barley and Sorghum Grains. Jordan Journal of Biological Sciences., Volume 7, Number 3, September .2014 ISSN 1995-6673 Pages 227 231.

Bekhit, M. M. M. (2007): Grain surface scan and cytological studies in a selected wheat line possessing the 4BS.4BL-5RL translocation. Annals of Agric. Sci. Moshtohor, 45 (2).

Bhagyalakshmi, K.; Vinod, K. K.; Kumar, M.; Arumugachamy, S.; Prabhakaran, A. J. and Raveendran, T. S. (2008): Interspecific Hybrids from Wild x Cultivated Triticum Crosses - A Study on the Cytological Behavior and Molecular Relations. J. Crop Sci. Biotech. (December) 11 (4) : 257 - 262.

Cadle, M. M.; Murray, T. D. and Jones, S. S. (1997): Identification of resistance to Pseudocercosporella herpotrichoides in Triticum monococcum. Plant Dis. 81: 1181-1186.

Cane K.; Spackman M. and Eagles H. A. (2004): Puroindoline genes and their effects on grain quality traits in southern Australian wheat cultivars. Australian Journal of Agricultural Research, 55: 89-95.

Charnet P.; Molle G.; Marion D.; Rousset M. and Lull-ien-Pellerin V. (2003): Puroindoline form ion channels in biological membranes. Biophysical Journal, 84: 2416-2426.

Chen Q F and Zhang Q Q, (1991): Comparative study on cytogenetics among pentaploid hybrids derived from emmer and hexaploid wheat. Southwest China Journal of Agricultural Sciences 4: 30-36.

Csóti I.; Bakó A.; Tamás L. and Gárdonyi M. (2005): Investigation of the starch-binding properties of wheat friabilin. Acta Biologica Szegediensis, 49: 29-30.

Day L.; Bhandari D. G.; Greenwell P.; Leonard S. A. and Schofield J. D. (2006): Characterization of wheat puroindoline proteins. FEBS Journal, 273: 5358- 5373.

Dubreil L.; Gaborit T.; Bouchet B.; Gallant D. J.; Broekaert W. F.; Quillien L. and Marion D. (1998): Spatial and temporal distribution of the major isoforms of puroindolines (puroindoline a and puroindoline b) and non specific lipid transfer protein of Triticum aestivum seeds. Plant Sciences, 138: 121-135. 
Dyke F. L. (1992): Transfer of a gene for stem rust resistance from Triticum araraticum to hexaploid wheat. Genome 35: 788-792

Fukuda K and Sakamoto S, (1992): Studies on unreduced gamete formation in hybrids between tetraploid wheat and Aegilops squarrosa $L$. Hereditas 116:253-255.

Gaines C. S.; Raeker M. O.; Tilley M.; Finney P. L.; Wilson J. D.; Bechtel D. B.; Martin R. J.; Seib P. A.; Lookhart G. L. and Donelson T. (2000): Associations of starch gel hardness, granule size, waxy allelic expression, thermal pasting, milling quality, and kernel texture of 12 soft wheat cultivars. Cereal Chemistry, 77: 163168.

Giacintucci, V.; Guardeno, L.; Puig, A.; Hernando, I.; Sacchetti, G. and Pittia, P. (2014): Composition, Protein Contents, and Microstructural Characterisation of Grains and Flours of Emmer Wheats (Triticum turgidum ssp. dicoccum) of the Central Italy Type. Czech J. Food Sci. Vol. 32, No. 2: 115-121.

Gill, B. S.; Dhaliwal. H. S. and Multani, D. S. (1988): Synthesis and evaluation of Triticum durum - T. monococcum amphiploids. Theor. Appl. Genet. 75: 912-916

Giroux, M. J. and Morris, C. F. (1997): A glycine to serine change in puroindoline $\mathrm{b}$ is associated with wheat grain hardness and low levels of starchsurface friabilin. Theor Appl Genet 95 : 857-864.

Giroux M. J. and Morris C. F. (1998): Wheat grain hardness results from highly conserved mutations in the friabilin components puroindoline $\mathrm{a}$ and $\mathrm{b}$. Proceed- ings of the National Academy of Sciences of USA, 95: 6262-6266.

Giroux M. J.; Talbert L.; Habernicht D. K.; Lanning S.; Hemphill A. and Martin J. M. (2000): Association of puroindoline sequence type and grain hardness in hard red spring wheat. Crop Science, 40: 370-374.

Greenblatt G. A.; Bettge A. D. and Morris C. F. (1995): The relationship among endosperm texture, friabilin occurrence, and bound polar lipids on wheat starch. Cereal Chemistry, 72: 172176.

Greenway, W. T. (1969): A wheat hardness mdex. Cereal Science Today 14: 4-7.

Greenwell P. and Schofield J. D. (1986): A starch granule protein associated with endosperm softness in wheat. Cereal Chemistry, 63: 379-380.

Heneen, W. K. and Brismar, K. (1987): Scanning electron microscopy of mature grains of rye, wheat and triticale with emphasis on grain shriveling., Hereditas 107: 147-162.

Hogg A. C.; Beecher B.; Martin J. M.; Meyer F.; Talbert L.; Lanning S. and Giroux M. J. (2005): Hard wheat milling and bread baking traits affected by the seed-specific overexpression of puroindolines. Crop Science, 45: 871-878.
Huebner F. R. and Gaines C. S. (1992): Relation between wheat kernel hardness, environment, and gliadin composition. Cereal Chemistry, 69: 148151.

Hussien T; Bowden R. L.; Gill B. S. and Cox T. S. (1998): Chromosomal location in common wheat of three new leaf rust resistance genes from Triticum monococcum. Euphytica 101: 127-131

Igrejas, G.; Gaborit, T.; Oury, F. X.; Chiron, H.; Marion, D. and Branlard, G. (2001): Genetic and environmental effects on puroindoline-a and puroindoline-b and their technological properties in French bread wheats. Journal of Cereal Science, 34: 37-47.

Igrejas G.; Leroy P.; Charmet G.; Gaborit T.; Marion D. and Branlard G. (2002): Mapping QTLs for grain hardness and puroindoline content in wheat (Triticum aestivum L.). Theoretical and Applied Genetics, 106: 19-27.

Jauhar P. P.; Dogramaci M. and Peterson T S. (2004): Synthesis and cytological characterization of trigeneric hybrids of durum wheat with and without ph1. Genome 47: 1173-1181.

Kalkan, F. and Palamanit, A. (2017): Scanning Electron Microscopy Images of Moistened Wheat Grains: Frictional Properties. Int'l Journal of Advances in Chemical Engg., \& Biological Sciences (IJACEBS) Vol. 4, Issue 1 (2017) ISSN 2349-1507 EISSN 2349-1515.

Laemmli, U.K. and Favre, M.(1973): Maturation of the head of bacteriophage T4. Journal of Molecular Biology, 80: 575-599.

Law, C. N. and Payne, P. I. (1983): Genetical aspects of breeding for improve grain protein content and type in wheat. Journal of Cereal Science, 1: 79-95.

Law, C. N.; Young, C. F.; Brown, J. W. S.; Snape, J. W. and Worland, J. W. (1978): The study of grain protein control in wheat using whole chromosome substitution lines. In: Seed Protein Improvement by Nuclear Techniques. International Atomic Energy Agency, Vienna, 483-502.

Li, S. P., and Liu, D. J., (1993): Cytological analysis on mechanisms of functional gametes formation in hybrids between Aegilops tauschii and Triticum durum-Haynaldia villosa amphidiploid. Acta Genetica Sinica 20: 68-73.

Loutfy, A. E. (1992): The seed morphology of the malvaceae and its taxonomic value., Ph.D., Fac. Sci. Ain Shams Univ., Egypt. 253 pp.

Orlovskaya, O. A.; I. N. Leonova, I. N. I.; E. A. Salina, E. A. and Khotyleva, L. V. (2016): Features of Chromosome Behavior in Meiosis in Common Wheat Lines Containing Genetic Material of Tetraploid Wheat Species. Russian Journal of Genetics: Applied Research, 2016, Vol. 6, No. 2, pp. 225-232.

MacRitchie, F. (1980): Physiochemical aspects of some problems in wheat research. In Advances in cereal Science and Technology. Vol III ed Y 
pomeranz American Association of Cereal Chemists, St. Paul, MN pp 271-326.

McIntosh R. A.; Dyck P. L.; The T. T.; Cusick J. E. and Milne D. L.. (1984): Cytogenetical studies in wheat: XII. Sr35, a third gene from Triticum monococcum for resistance to Puccinia graminis tritici. Z. Pflanzenzuechtg. 92: 1-14

Merker, G. B. A. and Tesemma, T. (1994) Cytogenetic studies in Ethiopian landraces of tetraploid wheat ( Triticum turgidum L.)., Hereditas 121: 45-52.

Mikulikova, Maniela (2007): The Effect of Friabilin on Wheat Grain Hardness., Czech J. Genet. Plant Breed., 43, (2): 35-43.

Miranda, L. M.; Perugini L.; Srnic, G.; BrownGuedira G.; Marshall D; Leath S. and Murphy J. P. (2007): Genetic mapping of a Triticum monococcum derived powdery mildew resistance gene in common wheat. Crop Sci. 47: 2323-2329

Moss, R. (1985): The Application of Light and Scanning Electron Microscopy During Flour Milling and Wheat Processing. Food structure, Vol. 4 No. 1: 135-141.

Morris C. F. and Massa A. N. (2003): Puroindoline genotype of the U.S. National Institute of Standards and Technology Reference Material 8441, Wheat hardness. Cereal Chemistry, 80: 674678.

Morris C. F.; King G. E.; Allan R. E. and Simeone M. C. (2001): Identification and characterization of near- isogenic hard and soft hexaploid wheats. Crop Science, 41: 211-217.

Morrissey, J. H. (1981): Sliver stain for proteins in polyacrylamide gels. A modified procedure with enhanced uniform sensitivity. Analytical Biochemistry. 117: 307-310.

Pasha, I.; Anjum, F. M. and Morris, C. F. (2009): Grain Hardness: A Major Determinant of Wheat Quality. Grain Hardness and Wheat Quality., vol. 511-522.

Perugini, L. D.; Murphy, J. P.; Marshall, D. and Brown-Guedira G. (2008): Pm37, a new broadly effective powdery mildew resistance gene from Triticum timopheevi. Theor. Appl. Genet.116: 417-425

Rahman, S.;Jolly J. C.; Skerritt J. H. and Wallosheck A. (1994): Cloning of a wheat 15$\mathrm{kDa}$ grain softness protein. European Journal of Biochemistry, 223: 917-925.

Salama, Hanan (2003): Taxonomic studies on the grains of some wild and cultivated taxa of poaceae. M. Sc. Thesis in Botany Fac. Agric.; Cairo Univ.

Sears, E. R. (1948): The cytology and genetics of the wheat and their relatives. Adv. Genet. 2: 239-270.

See D. R.; Giroux M. and Gill B. S. (2004): Effect of multiple copies of puroindoline genes on grain softness. Crop Science, 44: 1248-1253.

Sheibanirad, A.; Mirlohi, A.; Mohammadi, R.; Ehsanzadeh, P. and Sayed-Tabatabaei, B. E. (2014): Cytogenetic and crossability studies in hulled wheat collected from Central Zagros in Iran. Plant Syst Evol. 300:1895-1901.

Sini, Fatemeh G. and Arzani, A. (2015) Karyological studies in Triticum monococcum subsp. aegilopoides and Aegilops cylindrical species grown wild pairwise in west Iran. Rostaniha 16(2): 164-173 (2015).

Swan C. G.; Meyer F. D.; Hogg A. C.; Martin J. M. and Giroux M. J. (2006): Puroindoline b limits binding of puroindoline a to starch and grain softness. Crop Science, 46: 1656-1665.

Thomas, J.; Chen, Q. and Talbert, L. (1998): Genetic segregation and the detection of spontaneous wheat-alien translocations. Euphytica 100: 261-267.

Tomar S M S and Vari A K. (1995): Genomic affinity in wheat based on chromosome pairing in $\mathrm{F}_{1}$ hybrid. Genetic Research and Education: Current Trends and the Next Fifty Years. Indian Soc. Genetics Plant Breed. New Delhi. 1256-1264.

Tomar, S. M. S.; Vinod and Singh B. (2004): Distant Hybridization in Wheat. Indian Agricultural Research Institute, New Delhi. 160 pp.

Tranquilli G.; Heaton J.; Chicaiza O. and Dubcovsky J. (2002): Substitutions and deletions of genes related to grain hardness in wheat and their effect on grain texture. Crop Science, 42: 1812-1817.

Turnbull K. M. and Rahman S. (2002): Endosperm texture in wheat. Journal of Cereal Science, 36: 327-337.

Vallega, V. (1978): Search for useful genetic characters in diploid Triticum spp. Proc. 5th Inter. Wheat Genetics Symp. New Delhi. pp156-162.

Wang, H, Y.; Liu, D. C.; Yan, Z. H.; Wei, Y. M. and Zheng, Y. L. (2005) Cytological characteristics of $\mathrm{F}_{2}$ hybrids between Triticum aestivum $L$. and $T$. durum Desf. with reference to wheat breeding. J. Appl. Genet. 46(4): 365-369.

Zakowsky N. and Donald, A. M. (2004): Investigation of the fracture of wheat grains by Environmental Scanning Electron Microscopy. Proceedings of the 12th International ICC Cereal and Bread Congress, 24-26th May, 2004, Harrogate, UK A volume in Wood head Publishing Series in Food Science, Technology and Nutrition 2005, Pages 225-229. 